\title{
CREATED OF AN INTEGRATED QUALITY SYSTEM FOR THE PRODUCTION OF CANNED MEAT FOR CHILD NUTRITION
}

Elena VOLOSHINA, Department of Commodity Quality Management and Merchandizing, Russian State Agrarian University Moscow Timiryazev Agricultural Academy, 127550, Timiryazevskayast., 49, Moscow, Russia, yudakovaes@gmail.com (corresponding author)

Nina DUNCHENKO,Department of Commodity Quality Management and Merchandizing, Russian State Agrarian University Moscow Timiryazev Agricultural Academy, 127550, Timiryazevskayast., 49, Moscow, Russia, dunchenko.nina@yandex.ru

Arina ODINTCOVA, Department of Commodity Quality Management and Merchandizing, Russian State Agrarian University Moscow Timiryazev Agricultural Academy, 127550, Timiryazevskayast., 49, Moscow, Russia, odintsowaarina@ yandex.ru

Svetlana KUPTSOVA, Department of Commodity Quality Management and Merchandizing, Russian State Agrarian University Moscow Timiryazev Agricultural Academy, 127550, Timiryazevskayast., 49, Moscow, Russia, skuptsova@yandex.ru

Olga FEDOTOVA, Canned milk laboratory of the All-Russian Research Institute of Dairy Industry, Lusinovskayast., 35/7, Moscow, Russia, vnimi-fedotova@ya.ru

The development of an integrated safety and quality system at enterprises for the production of baby food includes measures thataimed at analyzing risks and identifying critical control points throughout the process. The article presents studies on the identification and analysis of hazards and assessing the severity of the consequences of their manifestation. In order to integrate, the international standards ISO 9001 and ISO 22000 were selected, on the basis of which the quality system processes were identified, the resources and requirements for them were determined, as well as the parameters for monitoring these processes, the criteria for evaluating the effectiveness and efficiency of the developed system were established. Within the framework of the integrated system, the main and interior processes were identified. The main processes include organization management processes, planning and implementation processes for safe and quality products, and processes for monitoring, analysis and improvement. Support processes include processes for managing the organization's personnel, its infrastructure and production environment, as well as processes for managing documentation and records of the system.

Keywords: child nutrition, HACCP, integrated system, quality, safety.

\section{INTRODUCTION}

Safety methods are worked in food production all over the world. The increasing risks of mass poisoning and foodrelated diseases are necessary tocreate systems at processing that can identify and control all possible dangers and eliminate them until the product reaches the consumer. This issue is most sharply for manufacturers of products for young children, which are a special risk group and products for which required enhanced control.

\section{MATERIALS AND METHODS}

In order to develop an integrated quality and safety management system, quality tools were used.

\section{The decision tree algorithm.}

The identification of critical control points in the development of the Hazard Analysis and Critical Control Points (HACCP) plan is carried out using the decision tree method recommended by Codex Alimentarius documents (Codex Alimentarius, 2019).

\section{Hazard Analysis Method.}

The method is used to determine the likelihood and severity of the consequences of a hazard. Experts using all available sources of information of practical experience, members of the HACCP group assess the likelihood of a hazard being realized on the basis of possible assessment options: almost zero, insignificant, significant and high. The severity of the consequences is evaluated by gradation: mild, moderate, severe, critical. Using the chart of risk analysis, build the border of acceptable risk with the coordinates of the probability of the implementation of a dangerous factor - the severity of the consequences (Dunchenko, 2012).

Copyright (c) 2019 The Authors. Published by Vytautas Magnus University. This is an open-access article distributed under the terms of the Creative Commons Attribution License (CC BY 4.0), which permits unrestricted use, distribution, and reproduction in any medium, provided the original author and source are credited. 


\section{RESULTS AND DISCUSSION}

At the first stage of the work, a detailed analysis of the technology for the production of canned meat for young children was carried out. It was revealed that the production of mashed meat with vegetable components consists of the following stages and basic operations:

- preparation of raw meat;

- preparation of butter, salt, onion;

- preparation of pumpkin puree;

- preparation of the broth and passivation of the onion;

- receipt and blanching of meat raw materials;

- preparation of semolina;

- preparation, fine grinding and deaeration of the mixture (dosing of the recipe components, mixing, regrinding, homogenization, deaeration);

- washing, sanitization, storage and supply of cans;

- pasteurization and packaging of the mixture;

- sterilization of the product, packaged in decorated cans and control of the cans of the product, packaging of cans in a shipping container.

In the next phase of work, a HACCP plan was drawn up. Each product released on the Russian market must meet safety requirements, of course, this also applies to products for baby food. The creation of the HACCP plan at the enterprise for the production of canned meat for baby food will create a technology, identify hazards in time and eliminate them (Moran, 2017). To determine critical control points (Table 1), the analysis of biological, chemical and physical hazardous factors was carried out, the probability of occurrence of risks and the severity of their consequences were determined.

The main sources of information in the development of the HACCP plan are:

- regulatory documents governing the requirements for raw materials, containers and packaging materials;

- sanitary norms and rules that apply to this area of activity;

- technical regulations of the customs union governing safety indicators;

- technological documentation of production.

Table 1. Critical control points for meat can production for child nutrition

\begin{tabular}{|l|l|l|l|}
\hline № & Critical control point & Type of inspection & Control limits \\
\hline CCP 1 & Meat preparing & Visual analysis & Meat temperature max of $+4^{\circ} \mathrm{C}$ \\
\hline CCP 2 & Mixing & Particle size & $\begin{array}{l}\text { Disparity for children at the age of 3-6, } \\
\text { every cycle control }\end{array}$ \\
\hline CCP 3 & Deaerating & Gas-phase reduction & $0,07 \mathrm{mPa}$, every cycle control \\
\hline CCP 4 & Process duration & $\begin{array}{l}\text { Total process duration from } \\
\text { blanching till sterilization }-1,5 \text { hour }\end{array}$ & Max of 1,5 hour \\
\hline CCP 5 & Sterilization & $\begin{array}{l}\text { Temperature and duration of } \\
\text { sterilization }\end{array}$ & $\begin{array}{l}\text { Temperature: } 120 \text { or } 125^{\circ} \mathrm{C}, \text { three times } \\
\text { in cycle control. } \\
\text { Time: } 30-40 \mathrm{~s}\end{array}$ \\
\hline
\end{tabular}

Also, when determining critical control points, the risk of food poisoning was taken into account, this is important for children of any age periodization. There are grave consequences of technology. Creating a mixture of inappropriate dispersion leads to the fact that the product is not absorbed by the child's body. Inadequate removal of air from the mixture leads to the development of microflora, and therefore to the development of severe diseases in children. Improperly organized sterilization of the finished product leads to spoilage of the product until the end of its shelf life.

From table 1 it is seen that the monitoring of Critical Control Point (CCP) is carried out in a certain period of time during the process. Each point has some measurable parameters in which it is necessary to control it (Cherksova, 2018). The organization of a traceability system in this industry is an important aspect in creating healthy and safe products for the next generation. In relation to the technology considered, the input control of raw meat received for processing is the first most important stage of the traceability system. It is necessary to fix the quality of incoming meat raw materials and auxiliary materials, information about the supplier, the presence of a veterinary certificate.

During the technological process, it is necessary to track the batch number of raw materials, record its use, and then test the resulting finished product. The batch number of the finished product is also fixed, which allows you to control it in the distribution network during implementation.

Thus, the identification of critical control points and the traceability system are interrelated activities. Together, the HACCP system operates, the technological process for the production of products for baby food is implemented and monitored (Hamrin, 2012).

Presentation of the technology and each process in it leads to the creation of a line of safe products. The task of technologists and workshop workers is to organize production so that each measured process parameter is monitored. Planning the stages of the technology, as well as the technology itself, guarantees the manufacturer the implementation of safe products, and the activities associated with the determination of CCVs allow you to strictly monitor the risks and avoid the release of defective baby food products. 
The third stage of the work included the integration of the HACCP security system and the quality system based on ISO 9000 standards. The creation of an integrated quality system in the food industry is the development of a system that meets the requirements of two or more management systems.

The creation of a model of an integrated system for managing safety and quality of products was carried out on the basis of the integrated use of the international standard MS ISO 9001: 2015 (ISO 9001:2015, 2015) and GOST R 51705.12001, reflecting, in general, modern principles and technologies for managing the quality and safety of food products(Hsiang Ru Chen, 2012; Dunchenko, 2018).

The main aim of creating such a quality system is to develop an action plan for its implementation in food technology. It is necessary to draw up an integrated system policy, to predict potential dangers and take preventive measures to eliminate them during the process.

At the stage of designing the system, international standards were selected, the processes of the organization to which the system applies are identified. Next, the sequence and interaction of the identified processes were established, their owners were appointed, responsible for their effective and efficient management. After identification of all processes, specific requirements of international standards were identified, parameters for monitoring processes, methods and tools for monitoring, measuring and analyzing processes were established, criteria for evaluating the effectiveness and efficiency of processes and the system as a whole were formed.

Based on an analysis of the provisions and requirements of ISO 9001: 2015, blocks of processes were formed that are implemented in the production technology of canned meat for baby food (Voloshina, 2017).

A generalized scheme of an integrated safety and quality management system for the production of canned meat for baby food was developed (Fig. 1), which is a conceptual model of an integrated system and implements a cycle of continuous improvement of PDCA (Plan-Do-Check-Act).

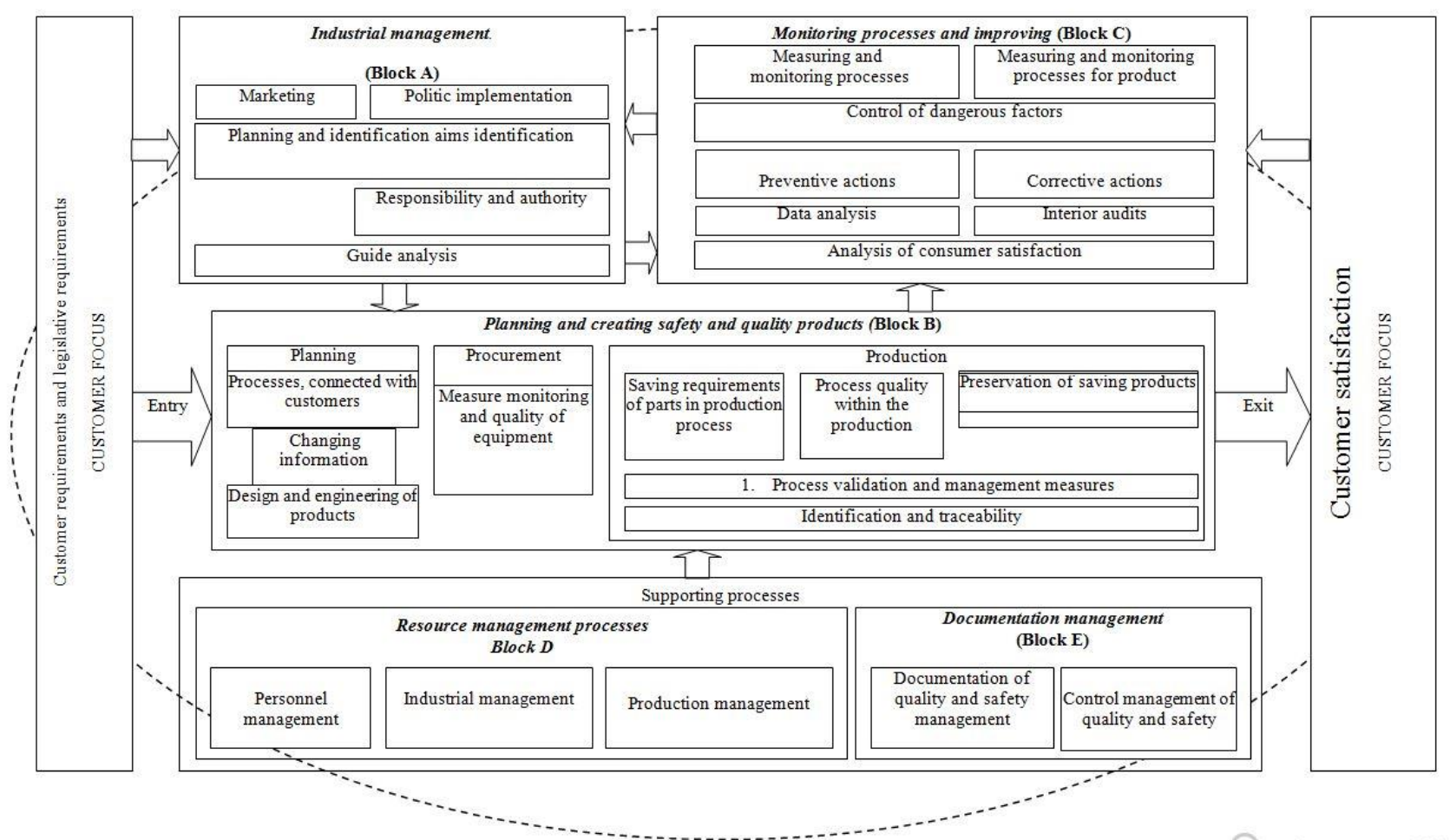

Figure 1. Conceptual model of integrated quality safety and management system

Within the framework of an integrated system, the main and auxiliary processes are distinguished. The main processes of the integrated safety and product quality management system include organization management processes (block A), planning and implementation processes for safe and quality products (block B).

This includes processes for managing the organization's personnel, its infrastructure and production environment, as well as processes for managing documentation and records of the system.

On the scheme of the integrated quality and safety management system in block B, such an important aspect is defined as traceability. In the production of canned meat for baby food, there are several points of organization for traceability:

- receipt of raw materials and their preparation;

- internal traceability - from which batch of raw materials was taken to prepare the mixture;

- output traceability - distribution of a product in a distribution network or storage in order to identify risks.

It is often difficult at meat processing enterprises to track the quality of incoming raw meat. The use of digital data in traceability for the food industry significantly increases production. It becomes possible to track the raw materials, obtain the necessary data, and then process it and get a quality product. Such an exit of technology to a new information level significantly reduces the influence of the human factor on the production process. 


\section{CONCLUSIONS}

For the modern consumer of meat products for baby food, information about the product made is of great importance: what raw materials were used, where it was obtained from, with what indicators and whether they comply with safety standards. The principle "from the field to the counter" and its correct implementation gives people a guarantee of product quality.

The developed integrated system of safety and quality allows us to improve the work of the entire enterprise, ensure coordination of actions, involve personnel in the work of the enterprise and provide continuous improvement, and of course provide the consumer with safe and quality products.

\section{REFERENCES}

1. Cherksova E.I., Golitsynskiy P.V. 2018. Organization of traceability of wheat flour quality. Competence, No 4 (155), pp. $43-47$.

2. Codex Alimentarius. International Food Standard, 2019. http://www.fao.org/fao-who-codexalimentarius/en/

3. Dunchenko N.I., Kuptcova S.V., Yankovskaya V.S. 2012 Food Safety and Hygiene. RSAU-MTAA. Moscow. p.153.

4. Dunchenko N.I., Voloshina E.S., Kuptsova S.V., Cherkasova E.I., Sychev R.V., Keener K. 2018. Complex Estimation of Effectiveness of Quality System Processes at Food Industry Enterprises.Foods and Raw Materials, Vol. 6, No. 1, pp. $182-190$. https://doi.org/10.21603/2308-4057-2018-1-182-190

5. Hamrin P. ,Hoeft B. 2012. Quality Control throughout the Production Process of Infant Food. Ann NutrMetab, Vol. 60, pp. 208-210 https://doi.org/10.1159/000338201

6. Ru Chen H., Bor-Wen C. 2012. Applying the ISO 9001 process approach and service blueprint to hospital management systems. The TQM Journal, Vol. 24, Iss. 5, pp. 418-432, https://doi.org/10.1108/17542731211261575

7. International Standard ISO 9001:2015 Quality management systems. Requirements. Geneva: ISO, 29 p.

8. Moran F., Sullivan C., Keener K., Cullen P. 2017. Facilitating smart HACCP strategies with Process Analytical Technology/ Current Opinion in Food Science, Vol. 17, pp. 94-99. https://doi.org/10.1016/j.cofs.2017.11.003

9. Voloshina E.S., Dunchenko N.I. 2017.Measurement of Quality Management System performance in meat processing. Theory and practice of meat processing, Vol. 2, No 3, p.21-30. https://doi.org/10.21323/2414-438X-2017-2-3-21-30 